\title{
CHRISTER KIHLMANS SJÄLVBIOGRAFI LIVSDRÖMMEN RENA (1982) I ETT POSTKOLONIALT PERSPEKTIV
}

\author{
JAN DLASK
}

\begin{abstract}
Christer Kihlman's Autobiography Livsdrömmen rena (1982;

The Clear Dream of Life) in a Postcolonial Perspective

This article deals with the autobiography Livsdrömmen rena (1982; The Clear Dream of Life), written by the Finland-Swedish author Christer Kihlman. It is his second so-called South America book and is based on the writer's own experiences from the early 1980s, when he visited several South American countries. The text is seen in a theoretical-methodological frame of postcolonial studies, i.e. the 1978 book Orientalism by Edward W. Said, which describes, how "the Orient", Oriental people and nations were viewed by their western colonizers. The analysis, which also takes into account Latin American postcolonial specificities, follows the article author's already performed interpretation of Kihlman's first South America book, Alla mina söner (1980; translated as All My Sons, 1984).
\end{abstract}

Keywords: Christer Kihlman; Edward W. Said; Livsdrömmen rena (The Clear Dream of Life); Orientalism; "Oriental features"; South America; dependency theory; Finland-Swedish literature; Finnish literature; 1980s literature; autobiography

\section{Postkolonial tolkning av Christer Kihlmans Livsdrömmen rena (1982)}

Den nyligen avlidne finlandssvenske författaren Christer Kihlman (1930-2021) blev känd efter sina samhällsengagerade böcker från 1960- och 1970-talet ${ }^{1}$, som bl a kritiserade den finlandssvenska överklassen vilken han själv hade rötter i. I början av 1980-talet skrev dock Kihlman två något annorlunda texter, de s k Argentina- eller Sydamerika-böckerna Alla mina söner (1980) och Livsdrömmen rena (1982). De båda är självbiografier i jag-form och är baserade på författarens egna upplevelser från 1970-talets slut och 1980-talets början, då han flera gånger vistades på den sydamerikanska kontinenten.

1 Se upp, salige! (1960); Den blå modern (1963); Madeleine (1965); Människan som skalv: En bok om det oväsentliga (1971). 
Denna artikel ämnar undersöka Kihlmans bok från 1982 ur ett postkolonialt perspektiv och påvisa hur Kihlman vidareutvecklar och kompletterar sina tidigare koloniala/ postkoloniala ${ }^{2}$ ämnen ur sin förra bok från 1980. Samtidigt vill den knyta an till några av de andra studier som finns om författarens Sydamerika-böcker. De är förhållandevis få; boken i fråga, Livsdrömmen rena, är därtill ännu mindre utforskad än dess föregångare Alla mina söner. Pirkko Alhoniemis kihlmanska monografi (1989) och Seppo Toiviainens samling essäer om Kihlman (1984) nämner den endast förbigående. Anja Kuhalampi (1994) har skrivit mera utförligt om maktens och olikhetens problematik i författarens båda Sydamerika-böcker, dvs också i Livsdrömmen rena. Alla de nämnda undersökningarna är finskspråkiga, så även Mikko Carlsons doktorsavhandling (2014). Den analyserar förhållandet mellan sexualitet och rum i sex av Kihlmans böcker som utgivits mellan 1971-1987. I den behandlas de båda Sydamerika-böckerna i var sitt kapitel, och ett av dem är således ägnat åt Livsdrömmen rena (jfr [121]-147). Det innehåller inalles tjugosju sidor och är den hittills mest omfattande studien om boken.

Carlsons utgångspunkt för detta kapitel är den andra Sydamerika-bokens samtida finländska reception, som skeptiskt såg den endast som en variation av Kihlmans tidigare verk, respektive som en fortsättning på självbekännelsegenren som Kihlman tidigare skrivit inom. Carlson frågar sig om en undersökning av sexualitet och rum i verket kan tillföra någonting nytt till diskussionen om författarskapet, och om det är meningsfullt att undersöka Kihlmans enstaka verk som fristående enheter; det implicita svaret i behandlingens slut blir jakande. Vid sidan om flera teoretiska ramar för textanalysen (teorier om pastoral, resebok eller nostalgi), vilkas användbarhet Carlson prövar, är det flera gånger som också det kolonialistiska perspektivet skymtar fram. Redan i början föreslår Carlson för Livsdrömmen rena att:

[...] [t]eosta voi lukea representaationa kokemis- ja kohtaamistavoista, joilla "meidän ja muiden" välisiä suhteita, kuten muukalaisuutta, toisen kohtaamisen vaikeutta ja kolonialistisen alistuksen kysymyksiä, tuotiin suomalaisessa kirjallisuudessa esiin hetkeä ennen jälkikoloniaalisen ajattelun laajempaa läpimurtoa. (125)

verket kan läsas som en representation av olika sätt att erfara och möta, där man belyser relationerna mellan "oss och andra", främlingskap, svårigheten att möta en annan och frågor om kolonialistisk underkastelse i finländsk litteratur strax före det bredare genombrottet av det postkolonialistiska tänkandet. (min översättning)

Carlsons påpekanden vad gäller den kolonialistiska tematiken ${ }^{3}$ är således biprodukter till undersökningens huvudtematik, sexualitet och rum, som kom till tack vare den syd-

2 I artikeln används begreppet postkolonial som hänvisande till det akademiska ämnet och den metodologisk-teoretiska apparaten, begreppet nykolonial med syfte att påpeka Sydamerikas formellt oberoende men ekonomiskt beroende ställning i tiden då boken utspelar sig, och begreppet kolonial i den allmännaste eller på den historiska koloniala eran syftande meningen.

3 a) Han ställer frågan på vilket sätt Livsdrömmen rena tillhör den europeiska reselitteraturtraditionen, som har producerat spända, "självberättigande" skildringar av relationer mellan kolonisatörer och koloniserade. b) Med hänvisningar till Edward Saids Den intellektuelles ansvar: 1993 års Reith-föreläsningar (Representations of the Intellectual) tolkar Carlson den grekiske diktarens Kavafis position mellan flera kulturer som parallell till "den frivillige landsflyktingen" Kihlmans (med anledning av dikten "Cavafys gåta", som är en metatext i Livsdrömmen rena; jfr 12-13). c) Han påpekar att den 
amerikanska miljön i vilken boken utspelar sig. Frågan är dock om en enhetligare teoretisk-metodologisk analysram för postkolonialistisk tolkning skulle kunna vara tänkbar. En sådan ram har redan använts i en annan undersökning som denna artikel vill knyta an till. Det är min egen engelskspråkiga analys av Alla mina söner (1980), Kihlmans första Sydamerika-bok. Analysen har också tagit avstamp i Carlsons förslag att se på boken ur ett kolonialt perspektiv (117-118), samt i en annan finländsk litteraturforskares, Pekka Tarkkas, syn på verkets tematik som ett möte mellan två olika världar och två olika värdesystem, som Kihlmans eget möte som medelålders europeisk och 'rik' intellektuell, med en ung, fattig, argentinsk homosexuell prostituerad innebär (11). Men det som jag framförallt gör i min analys är att tolka Alla mina söners breda spektrum av identiteter, mentaliteter och värden som ofta i texten står i motsats till varandra (se också nedan), i en teoretisk-metodologisk ram av Edward W. Saids bok Orientalism (orig. 1978).

I den utvecklar Said idén om "orientalism". Han beskriver hur västvärlden, speciellt Storbritannien, Frankrike och USA i egenskap av kolonisatörer, har skapat en imaginativ projektion av det koloniserade österlandet, den s.k. Orienten, i samband med Europas historiska expansion österut, som har haft sin både sin ekonomiska och politiska dimension. I den diskurs som enligt Said gradvis har konstituerats som en komplex struktur har nyckelrollen innehafts av ett konstgjort motsatsförhållande mellan de båda världarna: det primitiva och exotiska Öst och det rationella och civiliserade Väst. Inom diskursen har "Orientalister" från västvärlden behandlat den koloniserade Orienten och dess folk nedlåtande: de har konstitutivt och essentialistiskt setts som annorlunda i sitt tänkande och beteende än folken i Europa, och implicit som "lägre": för exotiska, excentriska, konstiga, misstänkta, primitiva, omänskliga, eftersatta och passiva (se Said passim samt vidare i artikelns text). Saids Orientalism har spelat en oerhört viktig roll inom postkoloniala studier.

\section{Postkoloniala studier och Latinamerika}

I Alla mina söners analys har jag funnit Saids teoretisk-metodologiska ram möjlig även för dikotomin Finland/Argentina, respektive (Nord)europa/Latinamerika. Det påkallar dock en diskussion om postkoloniala studiers ambivalenta förhållande till Latinamerika. Postkolonialism som begrepp och som konceptuell kategori har sedan 1980-talet uppstått i diskussioner om Afrikas och Asiens dekolonisering som inträffade efter det andra världskriget, i vilka Latinamerika berörts bara sekundärt. Detta gäller även Edward Saids egna texter: hans Orientalism riktar in sig på Asien, Nordafrika och Mellanöstern och det samma gäller t ex hans Culture and Imperialism (1993; Kultur och imperialism, på svenska 1995). Latinamerika har således blivit marginaliserat i postkoloniala studier - det saknas också en korpus av studier om vad som allmänt är godkänt som "postkolonialt".

västerländska mannens sexuella äventyr i tidigare kolonier, som är centrala i Kihlmans båda Argentina-böcker, skiljer sig väsentligt från de skildringar i internationell litteratur som beskriver den postkoloniala tidens sexuella turism. d) Med hänvisning till ett ställe (Livsdrömmen rena 116) påpekar Carlson att utgångspunkterna till att upphäva det koloniala maktsystemet ter sig problematiska, ty allt i Latinamerika, som inom kulturen uppfattas som värdigt och viktigt, kommer från första världen, samtidigt som en egen latinamerikansk kulturintelligentia betraktas som dissidenter (jfr Carlson 124-126, 141-143). 
Ett annat problem ligger i relationen mellan postkoloniala och latinamerikanska studier. Latinamerikanister förfogar över många egna reflexioner av Latinamerikas koloniala och postkoloniala historia som kommer från tiden före uppkomsten av postkoloniala studier. Deras reception av postkoloniala studier har varit blandad och många av dem har ifrågasatt teoriernas relevans för Latinamerika. De argumenterar att postkoloniala studier motsvarar de akademiska intressen som metropolita universitet har, de specifika realiteterna i Afrika och Asien och den position de akademiker som skriver om Latinamerika men inte kommer därifrån har, och förbiser således Latinamerikas egna kulturtraditioner. (Coronil 221, 222, 225-229)

Även om Latinamerika traditionellt betraktas som en del av tredje världen (Coronil 222), har det en särskild ställning i kolonialismens historia. Historien om motståndet mot Spaniens och Portugals imperialism, om antikoloniala rörelser under det tidiga 1800-talet och om antiimperialistiska rörelser under det sena 1800-talet och under hela 1900-talet är komplex och sträcker sig längre än 500 år bakåt i tiden. Den latinamerikanska befrielserörelsen i sin mest betydande del var däremot verksam under en ganska kort tid, 1808-1825. Strax efteråt började den postkoloniala tiden i Latinamerika, dvs tidigare än den egentliga koloniala eran annorstädes, och den har redan varat i nästan 200 år. (Young [193]) Trots alla skillnader påpekar Young dock att i nykolonialismens tid utsätts Latinamerika mer än någon annan region för USAs militära, politiska samt ekonomiska imperialism, vilket har till följd en politisk och ekonomisk maktlöshet och brist på egen kulturell identitet. Den ekonomiska ojämlikheten i Latinamerika liknar den som finns på andra kontinenter. De koloniala borgerliga revolutionerna som utfördes av vita europeiska bosättare, criollos, har inte frambragt frihet eller självbestämmelse för den lokala, ursprungliga befolkningen eller för slavarna. Latinamerikanska bönder lider fortfarande av akuta problem som extrem fattigdom och jordlöshet. Deras situation har blivit svårare i o m urbanisering och social uppdelning. Bondeuppror har kommit att bli ett konstant drag i Latinamerikas historia under de två senaste århundradena. De latinamerikanska regeringar som varit socialt revolutionära har genomfört jordreformer till förmån för de jordlösa. (Young [193]-194)

Som det mest betydande teoretiska bidraget till det postkoloniala tänkandet med en stark koppling till Latinamerika betraktas dependency theory, beroendeteorin. Den brukar tillämpas för det mesta i den ekonomiska, inte kulturella, sfären (jfr not 2). Rötterna till teorin går tillbaka till 1950-talet och den amerikanska marxisten Paul Baran. Hans tankar har på 1960-talet och senare vidareutvecklats av latinamerikanska och andra marxistiska ekonomer (Frank, Cardoso, Faletto, Furtado, Amin, Rodney, Wallerstein). Orsakerna till fattigdomen i de forna kolonierna i Afrika, Asien och Latinamerika ser beroendeteorin i deras underordnade ställning till deras före detta kolonisatörer. Deras underutveckling är en biprodukt av västvärldens utveckling. Det ligger i västvärldens intresse att likvidera de forna koloniernas lokala ekonomier, att hålla dem i stagnation, att exploatera dem genom att bedriva ojämnt handelsutbyte med dem. I den kapitalistiska ackumuleringsprocess, i vilken USA och övernationella företag sedan 1950-talet har spelat en dominant roll, har deras egna vinster varit viktigare än återinvesteringar till förmån för de forna koloniernas ekonomiska tillväxt. Även om många av dem formellt blev oberoende på 1950- och 60-talen, förblev de beroende ekonomiskt. (Coronil 223, Young 49-52, 201) 
I slutet av sin studie om Latinamerika och postkoloniala studier pläderar Coronil för en mer "taktisk" postkolonialism, som inte betraktar sig själv som ett avgränsat territorium, utan som ett expanderande stridsfält mot koloniala samt andra former av underkastelse. Samtidigt kritiserar Coronil tendensen inom postkoloniala studier att förbise vissa samtidiga former av politisk dominans och ekonomisk exploatering. Till stöd citerar han studiernas själva grundare, Edward Saids yttrande från 2002, där han tar avstånd från en sådan tendens som inte är tillräckligt medveten om nykolonialismens, imperialismens och "beroendestrukturernas" ihärdighet. Coronil anser att dialogen mellan postkoloniala och latinamerikanska studier inte borde vara polariserande. Han argumenterar snarare för en utvidgning av postkoloniala studier genom att bygga på latinamerikanska kritiska traditioner. Genom Latinamerikas inkludering i postkoloniala studier kan de postkoloniala studiernas geografiska verkningsfält och tidsperiod utvidgas, och deras perspektiv kan $\mathrm{t}$ o m fördjupas när vi upptäcker vad som förenar den moderna nordeuropeiska kolonialismens utveckling i Afrika och Asien med de spanska och portugisiska faserna i Syd- och Nordamerika, samt hur den grundar sig i dem (Coronil 238-240).

Denna studie, som pga sin tematik också måste ta hänsyn till det som är specifikt just för Latinamerika, vill likaså pröva en sådan utvidgning inom det litteraturvetenskapliga fältet.

\section{Kihlmans andra Sydamerika-bok jämförs med den första}

Min sista utgångspunkt för Livsdrömmen renas ( $L R s)$ analys är ett organiskt jämförelseperspektiv med Kihlmans första Sydamerika-bok Alla mina söner (AMS), och min tidigare ovan nämnda undersökning av densamma.

De både verken är uppbyggda på ett liknande sätt: som vidrörts ovan är Europa i AMS representerat av författaren/berättaren själv. Han blir kär i den tjugoårige argentinska pojken vid namn Juan som representerar Latinamerika i texten. Juan är en före detta sångare och gitarrist, men har också under flera år försörjt sig genom att sälja sin egen kropp, framförallt åt andra män. Samma modell förekommer likaså i $L R$, med den skillnaden att Juans roll har övertagits av en annan latinamerikansk gestalt, Kihlmans nya följeslagare, dvs den unge uruguayanske småkriminelle José4, som kommer från Montevideo men uppehåller sig i Buenos Aires.

Kronologiskt utspelar sig den något kortare $L R$ (181 sidor) efter AMS (284 sidor), dvs i början av 1980-talet, men har ingen direkt koppling till AMS i sin handling. Ändå finns det flera hänvisningar till Juan: den längsta av dem utgörs av ett avsnitt på fler än tio sidor (LR 55-68), där författaren vid ett möte med sin ambassadörsvän (se nedan) återberättar den förkortade historien om Juans rötter samt om sin relation till honom. Det är en historia som $A M S$ s tidigare läsare redan känner till och som på några punkter är något

4 Såsom Juans äkta namn var Aldo benämner Kihlman José som José Luis i en intervjubok från 2000 (se Westö - Kihlman 227-254). Med anledning av hur viktiga äkta namn är för den lejeunska självbiografiska pakten går det att diskutera om Livsdrömmen rena skulle kunna läsas som ett fiktivt verk istället för ett självbiografiskt sådant. 
modifierad i jämförelse med AMS. Författaren ser nu tydligare avigsidor hos gestalten (jfr 56, 59, 65), och allt - inklusive Josés närvaro - tyder på att författarens kontakt till Juan har avslutats. AMS utspelar sig huvudsakligen i Buenos Aires och andra delar av Argentina. $L R$ har en något bredare geografisk horisont: på författarens bekostnad företar de två männen en bilresa genom flera sydamerikanska länder: Argentina, Brasilien, Uruguay och Paraguay.

Flera av Carlsons formuleringar tyder på att analysen i $L R$, i den av honom föreslagna kolonialistiska riktningen, kan vara ännu mer produktiv än den i AMS. I centrum för den första Sydamerika-boken står vänskaps- och kärleksrelationen mellan jag-berättaren/författaren och den unga argentinaren, samt ett familjemönster som överskrider kulturella gränser. Den andra boken riktar däremot in sig på en främmande kultur, och resonerar kring skillnader mellan den och den egna kulturen, dvs författarens nordeuropeiska kultur. Även pastoral som genre, relevant för Carlsons tolkning av texten, behandlar ett kulturellt gränstillstånd eller en dialog som behandlar detsamma. Carlson visar senare att (och hur) $L R$ snarare fördjupar tematiken av kulturernas ömsesidiga växelverkan som redan är viktig i $A M S([121], 123,124,128,129)$.

I min egen tolkning av AMS (jfr Dlask) har den saidska analysramen (se ovan) visat sig vara ett produktivt verktyg: $A M S$ sett genom dess prisma innehåller en komplex och flerfaldigt ambivalent struktur vad beträffar det koloniala tänkandet. I boken erbjuder Kihlman en grundlig behandling av den tematik som Said har diskuterat: även om han själv implicit är under inflytande av orientalismens flertaliga fördomar, förmår han komma på det klara med hur det orientaliska tänkandet fungerar. Han lyckas dekonstruera många av dess aspekter och reflektera över att s.k. typiska eller gedigna orientaliska drag kan upptäckas även i Europa av utomstående, precis som Europa har upptäckt dem i Orienten. Jag har föreslagit att kalla $A M S$ "en alternativ finländsk eller finlandssvensk fick-Orientalism". Det kan vara intressant med avseende på att Saids bok (den första upplagan) och AMS (och i detta fall även $L R$ ) bara kom ut med två, respektive fyra års mellanrum $(1978,1980,1982)$, och med avseende på att Kihlman antagligen inte var bekant med Orientalism ${ }^{5}$. Precis som Carlson påpekat (125; se ovan), kom Sydamerika-böckerna ut ännu före det bredare genombrottet av det postkoloniala tänkandet.

Sammanfattningsvis: det är Carlsons påpekanden om den koloniala tematiken i $L R$, Saids Orientalism och det som är specifikt för det sydamerikanska postkoloniala, samt AMS och min egen redan utförda saidska analys av densamma, som ligger till grund för tolkningen även av LS. Samtliga utgångspunkter tillämpas vidare i tolkningen av Kihlmans andra Sydamerika-bok för att komma på det klara med hur författaren från Finland i Nordeuropa ser på sydamerikanska länder, med deras egna koloniala och nykoloniala historia.

5 Orientalism översattes till Finlands inhemska språk senare (till svenska år 1993 och till finska år 2011). Varken Said eller Orientalism omnämns i intervjuboken från 2000 som kartlägger Kihlmans liv och karriär som författare och intellektuell (se Westö - Kihlman). 


\section{Den uruguayanska despotism och den sydamerikanska polisiära makten}

Med anledning av AMS har jag påpekat att Kihlman vidrörde några av de typiska "orientaliska" dragen som Said funnit i sina källor, dvs grymhet och tendensen till barbari och despoti $(4,86,168,203,205,290,345)$. Så småningom kom dock författaren till slutsatsen att de inte var det han främst ville skriva om, med hänvisning till Sydamerikas specifika kontext och till att journalister kunde beskriva dem bättre än han (AMS 21, 75).

De här dragens analys utvecklas nu i $L R$ i en större omfattning. Uruguay beskrivs som ett land från vilket fattiga flyr till andra länder där det råder ett människovänligare styrelsesätt, och ett land där militärdiktaturen kväver och utplånar nästan allt fritt gestaltande och självständigt skapande (26). När författaren och José träffar en liten man utan tunga förklarar folket att han för några år sedan drabbats av en svår sjukdom men vill inte gå närmare in på detaljerna. Berättaren relaterar det plötsligt till det faktum att just för några år sedan var upprorets och den blodiga reaktionens år, Tupamoros ${ }^{6}$ tid (28-29). Argentinas politik, som enligt berättaren bedrivs på de maktberusade personintrigernas primitiva plan, jämförs i sin tur med 1600-talets Europa, där politiska motståndare lönnmördades på löpande band utan straffpåföljd (115). De hemliga säkerhetsmännen, de som desarmerar de kulturella företeelser i Argentina som ses som farliga (Sigmund Freud, Gabriel García Márquez), är utbildade av Pentagon (116) - vilket kan tolkas som ett indirekt uttryck för USAs politiska samt militära imperialism som Young nämner (194).

Även många av Josés släktingar och bekanta dog en grym död under den här tiden, andra sitter fortfarande inspärrade i fängelset för politiska fångar. Läsaren får ta del av Josés egna traumatiska minnen från Montevideos fängelse där han satt efter ett misslyckat försök till kassarån, ett inbrott i en textilaffär. Under flera dygns förhör hade han en huva knuten runt huvudet så att han ingenting såg och hade svårt att andas. De rakade av honom håret, han blev grovt misshandlad och $\mathrm{t} \mathrm{o} \mathrm{m}$ torterad, den dåliga fängelsematen kunde han inte få i sig. Sedan kom dock plötsligt och oförmodat hans villkorliga frigivning och det visade sig senare att den varit en följd av något byråkratiskt misstag som skett vid handläggningen av de fångnas papper (152-153).

En tolkning härav kan vara att grymhet, barbari och despoti förekommer, men att det också finns luckor i systemet. Detta stödjs av ett annat ställe i texten, som beskriver en av den sydamerikanska narkotikasmugglingens huvudleder i Misiones i Argentina, där poliser är avlägsna, halvtama och till sist självfallna, avväpnade, tandlösa, ”[...] ty i detta brännande klimat upphör all moralisk och byråkratisk effektivitet att fungera." (117-118).

Även författaren själv kommer i närmare kontakt med sydamerikanska polisiära myndigheter under resan. Det första mötet sker på landet i Uruguay när han och José råkar ut för en bilolycka som förorsakats av fyra hästar (se även nedan). Kort efter olyckan blir de omringade av beslutsamma uruguayanska poliser med gevär, som sett att bilen körde för fort när den passerade deras station för en stund sedan. De två männens bagage blir

6 En väpnad organisation bildad i Uruguay 1963 som under flera decennier bekämpade landets militärdiktatur. 
noggrant genomsökt redan på plats, mitt på vägen, sedan förs de till polisstationen och förhörs separat (95-98).

Den repressiva makten visar sig dock vara verkningslös. Även om minst sju poliser vankar betydelsefullt av och an från rum till rum med de bådas pass, olika protokoll och dokument, ställer nya och åter nya frågor, för allvarliga diskussioner med varandra och ringer många telefonsamtal, upptäcker ingen att José blivit villkorligt frigiven bara några månader tidigare från fängelset (vilket skulle försvåra situationen väsentligt). Poliserna fäster inte ens något avseende vid att de anhållnas andedräkt luktar starkt av whisky som de förtärt under den föregående resan (vilket skulle vara det mest graverande i den europeiska Norden). För författarens del blir det snarare ett rutinförhör med ovidkommande byråkratiska rutinfrågor om utlänningens identitet och skäl till vistelsen i landet. Precis som berättaren kommenterar, kan polisernas noggrannhet snarare ses som en strävan mot att få lite omväxling i enformigheten när de är stationerade så här i ödemarken (ibid).

Efter att ha fått vänta länge - dock över en kopp te så att de kunde värma sig i morgonkylan - blir männen frisläppta och får bara en liten reprimand för att ha kört "poco r[á]pido", lite för fort, men inte några böter alls. Josés muta avvisas bestämt med påpekandet att Uruguay inte är som det genomkorrumperade Argentina. Bilden av tama, nästan godmodiga poliser, som istället för med polisbil kommer gående med gammalmodiga automatgevär till olycksplatsen och först försäkrar sig om att ingen människa är skadad, för att därefter beställa en taxi åt de två männen till den närliggande staden Artígas och ge dem adressen till en man därifrån som äger en bärgningsbil (jfr ibid), stämmer illa med föreställningen om en despotisk stats totalitära myndighet som vid varje tillfälle förföljer misstänksamma personer. Av beskrivningen går det snarare att döma att den uruguayanska polisen är en serviceinrättning, beredd att tjäna allmänheten.

Det andra tillfället att av egen erfarenhet lära känna den sydamerikanska polisiära makten kommer när de två männen passerar gränsen från Brasilien till Argentina. Här kommenteras avsnittet i början med reflexionen att de svårigheter en privatperson utsätts för vid gränsstationerna tydligen står i viss proportion till graden av hårdhet hos landets regim (108). En ung argentinsk passpolis börjar skrika obehärskat och pratar länge: Kihlmans pass saknar alla viktiga stämplar, de tillstånd och visum det innehåller är ogiltiga och han har tidigare passerat gränserna illegalt. Han har dock inte tid att diskret muta polisen, som Josés stumma gest rekommenderar, ty det kommer plötsligt en annan passpolis i högre tjänsteställning, slår själv in stämpeln i Kihlmans pass och överräcker det åt författaren med en liten bugning. Hans unga kollega ber därefter José om att få smaka på en uruguayansk cigarrett ur hans ask och bjuder själv på sina argentinska cigarretter. Männen röker en stund och sedan lommar författaren och José iväg medan andra människor som passerar gränsen blir noggrant undersökta av tullen (LR 108-111).

På ett annat ställe skriver Kihlman vad gäller despoti och korruption i Argentina illusionslöst: "[...] rättvisans gudinna är tecknad i blodig skrud med batong och maskinpistol. Hennes hand är utsträckt till försoning, men tryck en sedelbunt däri och hon låter sig utan protester bestigas och utnyttjas för grymma njutningars behov.” (LR 115) I det ovan beskrivna fallet tog dock de uruguayanska poliserna fel: inte ens argentinarna ville ta emot någon muta. Frågan är om de sydamerikanska myndigheternas beteende överhuvudtaget är förutsägbart och tolkbart, som berättaren anmärker: 
Så är det alltid i Argentina, åtminstone på denna nivå. Ibland går det, ibland går det inte alls. Och det som var olöslig komplikation den ena minuten är lappri den andra. $(111)^{7}$

LRs slut innehåller två korta händelser där det förekommer lokala poliser. På en fest vid kyrkan i en liten argentinsk by vill José köpa olja till sin bil, men ingen bybo har någon att avstå. Till sist köper han en halv liter av polisen (174). När männen kör ut ur småstaden Obera ${ }^{8}$ (se nedan), vinkar den småleende trafikpolisen på torget och gör honnör; ett par dagar tidigare har de parkerat bilen fel och polisen har bara vänligt påpekat det för dem utan att bötfälla dem (178).

Helhetsbilden av den polisiära makten som läsaren får beskriven för sig går knappast att relatera till en odemokratisk statsbildning som vill bedriva sitt skräckvälde; en delorsak till det kan också vara dess ineffektivitet (jfr LR 101).

\section{Lunch med ambassadören: att ändå älska Argentina}

Det andra kapitlet i $L R$, "Alexandra" (35-68), betecknar namnet på en restaurang i Buenos Aires dit berättaren kommer en dag vid lunchtid. Stället vimlar av välklädda utländska affärsmän från Australien, Sydafrika, Tyskland, England, Skandinavien, Spanien och Holland. De är redan argentiniserade, men upprätthåller fortfarande kontakterna till sina gamla hemland vars exportmarknader erbjuder dem deras levebröd. Deras uppförande beskrivs som en smula överlägset: de föredrar att tala engelska när de umgås sinsemellan fast de också kan spanska flytande, de talar med större ljudvolym än infödda argentinare, kritiserar Argentinas odugliga regering och den argentinska byråkratin (35-36). Bilden av sällskapet, där "[a]lla är någon, [...]“ (36), kan ses som en symbol för den nykoloniala makten som exploaterar det formellt oberoende, men egentligen ekonomiskt beroende sydamerikanska landet. Den kan tolkas som en öppning till samtalet som författaren kommer att föra under lunchen med sin vän han väntar på. Även barbari- och despotitematiken kommer att utvecklas vidare under samtalet.

Vännen är Finlands kontroversielle ambassadör i Argentina. Diplomaten har blivit förflyttad till Buenos Aires från Washington på grund av sin frispråkighet. Men ännu en gång tänker han visa sin uppriktighet, dvs professionellt vanhedra sig genom att vägra motta en argentinsk orden. Syftet är att uttrycka ett protest mot den lojalitet - rättare sagt mot det hyckleri - som han i sin ställning är förpliktad till, även i en tid då hans tre bästa argentinska vänner förts bort av diktaturens civilklädda tjänare och blivit spårlöst försvunna $(41,52,54,55)$.

Den för vårt ämne intressanta delen av samtalet som förs mellan Kihlman och ambassadören har en symptomatisk struktur och kan sägas bestå av tre avsnitt. I det första diskuteras argentinska förhållanden och männen vidrör också despotifrågan flera gånger. Det talas om den argentinska jorden som är den bördigaste i världen, men är obrukad och outnyttjad pga att den tillhör privata ägare - ty tre procent av befolkningen äger över nittio procent av den, men en omfördelning är i dagens aktuella läge ogenomförbar. Att

7 Jfr en parallell episod ur AMS (64-66), då först efter lång väntetid och många förödmjukande frågor släpps Juan slutligen av den argentinska passpolisen för att åka med båt till Montevideo.

8 Den spanska rättstavningen är Oberá. 
regera i Argentina är att hävda ett kapitalistiskt privatintresse mot ett annat sådant, över huvudet på det stumma folket. Det har alltid varit så att de mäktiga är alltför mäktiga, och de maktlösa utan någon makt alls. Den argentinska politiken saknar raffinemang, man bryr sig inte om att kamouflera att människa är människas varg. Den politiska själviskheten, våldet, terrorn, tortyren och stora klasskillnader har en lång tradition, som leder tillbaka ända till landets självständighetsförklaring i början av 1800-talet (42-45).

Despotin ses alltså som ganska essentialistiskt inbyggd i Argentina - precis som även Said påpekat för Orientens del $(4,203,205)$. De samtalande männens repliker om jordfrågan överensstämmer i sin tur med Youngs karakteristik av de akuta fattigdoms- och jordlöshetsproblem som latinamerikanska bönder lider av. De tyder också på de argentinska regeringarnas socialt orevolutionära anda och föga intresse för att genomföra jordreformer till förmån för de som inte äger någon jord (se ovan; jfr Young 194).

Dock, så snart som en av debattörerna - oklart vilkendera - säger sin replik " - Koloniala ressentiment och nykolonialt förtryck eller åtminstone tryck - norrifrån“ (45), kommer berättarens patetiska och paradoxala bekännelse att han älskar Argentina. Ambassadören nickar samstämmande och medger att han ibland upplever detsamma. Orsaken därtill hänger samman med hans ifrågasättande av sättet på vilket nyheter från Argentina presenteras i europeisk press (ibid).

Frågan om den argentinska despotin förskjuts nu, i samtalets andra avsnitt, till frågan om på vems och på vilka villkor den europeiska bilden av Argentina uppstår - som kan jämföras med Saids allmänna fråga om på vems och på vilka villkor västvärldens bild av Orienten uppstått. Varken de utländska affärsmännens, journalisternas, Kihlmans eller ambassadörens bilder liknar argentinarnas egen av landet. (47-48).

Det godtyckliga våldets Argentina är nämligen inte hela Argentina. Den dagsjournalistiska bilden av Argentina i Europa [...] är sann, men ungefär som om man delade en människa mitt itu och höll upp hennes underkropp och sade: detta är en människa, för bilden är en hatbild, [...] framsprungen ur det hat den starke känner när lusten föds att slå den redan slagne, att förakta den svage för hans svaghets skull och att ytterligare förödmjuka den av sina egna svårigheter redan tillräcklig förödmjukade. (46)

För den europeiska journalisten finns det aldrig någonting positivt att säga om det argentinska folket som trakasseras av brutala härskare om hen tacklar tematiken som hen gör, såsom Kihlman formulerar, "[...] med hela sin egenrättfärdighets skenhelighet från kristendomens historia inlärd, [...]” (46). På avstånd verkar sedan de politiska och ekonomiska förhållandena i Argentina upprörande och grymma, och europeiska tidningsläsare föreställer sig att det som står i reportagen om diktaturens generaler, överstar och korpraler är hela sanningen. På så vis blir det naturligt för dem att förakta och avfärda Argentina, att inta en överlägsen attityd samt att avge en sträng moralisk dom. Landets främmande folk blir på så vis sett som en abstrakt mänsklig massa utan individuellt ansikte, och som läsare i Europa förbiser man att även i fjärran länder, precis som hemma, finns en helt vanlig mänsklig vardag (47-48).

Såsom redan vidrörts ligger alltså orsaken till att Argentina betraktas som ett despotiskt land i mönstret med vilket man väljer att se landet - så här kan man också sammanfatta Said mest allmänna tanke i Orientalism. Enligt Kihlman kan endast de som har sett 
mera av Argentina än det som det internationella skvallret innehåller, som författaren själv och hans vän ambassadören, också lära sig älska det här landet. (47)

För vi har förstått att de grymma bulletinerna om koncentrationsläger och våld och oförklarliga försvinnanden, när de når Europa, mindre handlar om det lidande Argentina än om det demokratiska mottagarlandets lystna förväntningar. (45)

Efter att ha kritiserat argentinska förhållanden och problematiserat perspektivet från vilket denna kritik framförs, följer samtalets tredje avsnitt. Männen fortsätter att presentera sina kritiska synpunkter på Argentina, men då i jämförande perspektiv med Finland ${ }^{9}$. Här omnämns parallellerna mellan de argentinska och finska nationella myterna, Argentinas och Finlands behov av förenklande nationella symboler, de båda ländernas osäkerhet och känsla av mindervärde i förhållande till andra mer tongivande nationer, samt frågan om argentinarnas självförståelse, deras luftslott, överdimensionerade övermod och självtillräcklighet, skrytsamhet över prestationer, drömmar som uppkommit ur en djup och genomgripande nationell frustration, upplevd under generationer - som hos finnarna uttrycker sig annorlunda: i en frivillig underkastelse när de som tigande drar sig tillbaka och gömmer sin underlägsenhet i buteljens dimma (48-50).

Min tolkning är att även om det finns många saker i Argentina som kan kritiseras betyder det inte att sådana inte finns i hemlandet; samma attityd uttryckte Kihlman i $A M S$ (jfr Dlask). Genom de här jämförelserna markeras således implicit ett avstånd från det orientalistiska tänkandet, för vilket hemlandet alltid är någonting "värdigare".

\section{"Den grå massan" och andra fördomar}

En av idéerna som presenteras under Kihlmans och ambassadörens samtal, den om att Argentinas folk ses som en abstrakt massa utan individuellt ansikte av Europa (se ovan), kan ses som en av fördomarna inbyggda i orientalismen: Orienten understryker nämligen konformitet och det orientaliska folket har ingen individualitet (Said 48, 287). I analysen av AMS behandlade jag att Kihlman genomgick en gradvis utveckling i texten: i flera fall var han mottaglig för att uppleva det argentinska folket på det här sättet, för att till slut i en enda mening göra sig kvitt med det här perspektivet (jfr Dlask). I den andra Sydamerika-boken $L R$ fortsätter författaren vidare att dekonstruera denna synvinkel.

Att författaren i $L R$ inte rör sig bara i en sydamerikansk stat, som han gör i $A M S$, hjälper honom att träda ut ur en ond cirkel i vilken han bara ser konformiteten. Det innebär också att han ser klarare skillnader mellan de enstaka länderna. Han är från allra första början angelägen om att presentera de olika sydamerikanska folken som nationer som har fördomar mot varandra, tänker i stereotyper (dock ibland motsägelsefulla) och som drivs av en ömsesidig rivalitet (såsom redan nämnts ovan). Som uruguayan tycker José att folk är hyggligare i Uruguay än i Argentina, där folk är råskinn, saknar folkvett, är obildade och ociviliserade (111). Ändå föredrar han att leva i Buenos Aires istället för Montevideo, som är en småstad med lugn rytm och obefintliga inkomstmöjligheter (76).

9 I motsats till $A M S$ jämförs Sydamerika i $L R$ enbart med Finland, inte med Sverige. 
Men också berättaren själv pekar på skillnaderna mellan länderna. Det är inte bara en fråga om att landskapet i Brasilien är annorlunda än i Uruguay (106) eller att prostitution i Argentina är officiellt förbjuden i motsats till i Uruguay (134). Skillnader kan ligga i samhällsformen och i styrkeförhållandet mellan enstaka stater. Uruguay är presenterat som ett land inklämt mellan de två självmedvetna jättenationerna Argentina och Brasilien, och har därför inte mycket att hävda sig med i konkurrensen, och ett land där de tjugo familjernas grymma obarmhärtiga samhällsform är ännu mera påtaglig än i Argentina (26). Skillnader kan också finnas i sättet att klara av förtryck och lidande:

Ögon. Människoögon. I Chile såg jag dem, mötte blickarna och de var ännu fyllda av trots, av öppet hat mot förtrycket, av beslutsamhet och kamplust, en okuvlig vilja och beredskap att inte ge upp, att segra till sist även på bekostnad av gränslöst lidande. I de argentinska ögonen finns det livsvilja, liknöjdhet eller högmod, en lust att överleva, samtidigt en tyst resignation, men med bevarad självkänsla. Medan här i Uruguay ögonen är som mörka stenar, uttryckande något därifrån man skrapat bort allt som betecknar hopp och förväntan, blickarna tunga av behärskat lidande och en tålmodighet redan många gånger prövad till bristningsgränsen, en resignation utan förmildrande inslag, en underkastelse utan förväntan på nåd och förbarmande. (26-27)

Konformitetstematiken har ännu en för $L R$ viktig dimension. Redan i början av texten (29) tar berättaren upp frågan om Josés självuppfattning. Formuleringen "I denna skuggvärld, detta Uruguay, där nästan ingen är mer än ingen." fortsätter med Josés egna ord "'yo soy nadie', jag är ingen" (ibid). Berättaren frågar sig: "En droppe i människohavet. En partikel i den grå massan. Var är den grå massan? Finns den?” (ibid) För iakttagare på maktens piedestaler kan den te sig som en verklighet, men träder man ner från piedestalerna och går in i den upphör den att finnas. Ingen är bara benämningen på ett oräkneligt antal människor som saknar inflytande över sitt eget liv, men som egentligen bildar en ström av enskilda individer, alla i grunden lika ovärderliga. Ordleken slutar på samma sida med meningen "Ingen är ingen." Slusatsen angående José, som hjälpt författaren att förverkliga hans dröm, är: "José ingen? Aldrig i livet. Tvärtom. José prinsen!" (30). Det här leder berättaren som "[...] frihetens lyckoprins, välståndets gullgosse [...]" (89) att retoriskt ta avstånd från maktens människor och slå följe med de maktlösa, med de oansenliga i den grå massan (117).

Den här dimensionen, som i $L R$ tätt hänger samman med den ovan behandlade despotifrågan, är i linje med Kihlmans bild av Sydamerikas samhälle redan från AMS. Uruguay presenteras som ett utvandrarland som miljoner redan lämnat. De rika maktägarna välkomnar samtliga som försvinner därifrån, ty kakan är liten och räcker inte till för alla, och den största delen ägs av dem som inte vill dela med sig. Fattigdomen hindrar dock de fattiga att förflytta sig. Klyftan mellan de rika och de fattiga är stor: klasskillnaderna är större än i Victorias England (88; jfr även 26) ${ }^{10}$.

Den orientaliska exotismen och fatalismen (jfr Said 290, 345) har i samband med AMS tolkats i mysticismens och magins tecken som ibland förekommer i Argentina: man har sett andar och tror på deras existens (jfr Dlask); motivet upprepas också i $L R$ (158).

10 För mer om sydamerikanska fattiga i $L R$ jfr även Carlson 135-136, 142-143. 
I analysen av AMS märks ett av Said upptäckt "typiskt orientaliskt" drag, "ovänlighet mot djur" (Said 38), med en scen när berättarens argentinska kamrater kör över en hund med sin bil och är helt oberörda av olyckan (AMS 25). Episoden kan läsas i dialog med $L R$ : under författarens resa tillsammans med José ses många både vilda och tama djur - bl a mycket boskap som ofta rör sig kring vägkanten - och ingenting liknande inträffar. Den enda liknande händelsen är under en fortkörning på natten i Uruguay. Då upptäcks en grupp av fyra hästar stå på vägen. De blir sedan orsaken till en bilolycka, fast ingen av hästarna eller de två männen skadas (se även ovan). Det visar sig dock efteråt att hästarna räddade de två männens liv genom att stå på vägen en liten bit framför en mycket farlig plats på körbanan, som man inte ser förrän det är för sent, särskilt på natten. På platsen hade redan många förare, särskilt i hög fart, omkommit förr (92-93, 101-102). I denna tematik kan man således se en tidsmässig idéutveckling: i början körs djur över ( $A M S)$, efteråt räddar de ens liv $(L R)$.

Även andra ämnen Kihlman tidigare varit inne på i AMS upprepas, modifieras eller utvecklas i $L R$, men några av dem ses inte längre som produktiva att diskutera djupt. Ett av dem är "[s]olidaritet av nöden dikterad" (154), som de fattiga visar till varandra. Med erfarenhet av umgänget med Juan och hans vänner accepterar berättaren utan några djupgående etiska eller moraliska analyser om lögner ${ }^{11}$ att hans resekamrat José är småkriminell $(105,149)^{12}$. På samma sätt blir det accepterat att José som bilchaufför kör alldeles för fort och förtär whisky under resan som vanligt är i sydamerikanska trakter (LR 30, 91, 107), där livet inte är bundet med den nordiska välfärdens tusen och ett reglementen (jfr AMS 122). Sydamerika brukar inte se på vissa fenomen som patologiska - $\mathrm{t}$ ex tiggeri, triangelrelationer, transvestism eller företeelser inom sexhandel $(L R 26,138$, 139, 148, 149) - vilket Europa gör.

I AMS analyserar Kihlman både kritiskt och djupgående den argentinska maskuliniteten, i $L R$ ägnas mycket mindre plats åt ämnet: Josés föräldrar ses som medlemmar i patriarkal familj, där modern är tålmodig, förstående och förlåtande men fadern är auktoritär, krävande och känslomässigt trubbig och blockerad (146). Formuleringen ”José i de maskulina konflikternas våld" (144) tyder dock på en mer ifrågasättande attityd i $L R$ än den stabila maskulinitetsbilden i AMS. På ett mer nedtonat sätt än i AMS sker också beskrivningen av ett av de viktigaste dragen som västvärlden förknippar med orientaler: exotisk sensualitet och odifferentierad sexualdrift (se Said 4, 72, 167, 190, 203, 205, 311, 345). Intressant är att en rak sexualitetsbeskrivning förekommer just i samband med Juans historia (LR 60-61). Men även om José precis som Juan har erfarenheter av att ha varit taxi-boy, dvs prostituerad homosexuell (147), och även om han också hela tiden är på jakt efter flickor $(161,176)$, ägnas ingen stor uppmärksamhet åt saken av LRs berättare. LR innehåller två sexuella scener (jfr 129-131, 139-141) som är rakare än de i AMS - den ena innefattar en homosexuell relation och den andra en heterosexuell sådan - och det är den västerländska berättaren som är delaktig i de både. På så vis kommer läsaren inte att förstå sydamerikaner som mer sexuella varelser än européer - den tolkningen kunde man lättare dra i $A M S$ (jfr Dlask).

11 Lögner hör enligt Said också till de drag som brukar förknippas med orientaler (se 38-39).

12 Den enda analysen är en relationsmässig och psykologisk sådan (jfr LR 144-157). 


\section{Besök hos en rik man}

Ur det nykolonialistiska perspektivet är avsnittet då författaren och José besöker "[...] en rik man med makt [...]" (119) ytterst viktigt. Nu pensionerad lever han med sin familj och tjänstefolk i den argentinska staden Posadas i en polisbevakad lyxvilla omringad av en storslagen trädgård. Här uppstår länken till det som ambassadören i samtalet påpekat, att " - Argentina är en förvisningsort för nazistiska officerare och misslyckade diplomater, [...]“ (43), ty den rike mannen bär ett tyskt efternamn. På 1940-talet var han ökenkrigare, därefter framgångsrik affärsman i Sydamerika som blev rik under Peróns ${ }^{13}$ välde tack vare dennes uppfattning att tyskar kunde sköta Argentinas ekonomi bättre än argentinarna själva. Och även om han inte alltid varit övertygad om regeringarnas kompetens efter Perón har detta inte hindrat honom att samarbeta också med dem (LR 119-122). Här presenteras ännu en gång en gestalt som i beroendeteorins anda lyckats dra materiell nytta av Sydamerikas mindre sinne för den internationella kapitalismens affärsrealiteter.

Under en knapp timmes samtal försöker mannen förklara varför Argentina aldrig kommer att uppnå det blomstrande ekonomiska välstånd som dess naturrikedomar egentligen möjliggör. Han berättar om

[...] den argentinska folkmentaliteten, om lättjan och bristen på uthållighet, om själviskheten och det primitiva beroendet av stundens njutning och om oförmågan att se saker och ting ur ett större perspektiv, än den egna navelns. Argentinaren saknar fosterlandskänsla, [...] hans mage är hans fosterland, möjligen innefattande även områden mellan ljumskarna [...], han saknar följaktligen helt och hållet den europeiska dygden, att vilja och kunna offra sig för ett ideal, för helheten, för en stor nationell vision. (122).

Med egna ord kallar berättaren/Kihlman mannens tolkning, som han hört många gånger förut, för cynismer, ibland vitsigt formulerade och ibland bara hånfulla. För honom är den en lektion i överklass- eller uppkomlingssnorkighet, det är en tolkning som är vulgär, rasistisk eller skräddarsydd enligt ignoranta behov hos den sociala makthierarkins topp (LR 121-122).

Mannens ord om stora nationella visioner och fosterlandskänslan lär härstämma från hans tid som ung i Nazitysklands armé. Från vårt perspektiv är det dock mer intressant hur han i ett så kort avsnitt lyckas koncentrera flera av orientalismens fördomar som upptäckts av Said. Vid sidan av den ovan behandlade sexualiteten är det lättjan (Said 345) samt brist på objektivitet (Said 48). För det kolonialistiska perspektivet är det även symptomatiskt att den rike mannen behandlar den närvarande José öppet nedlåtande, Kihlman känner sig bli behandlad reserverat. Vid avskedet säger dock mannen till Kihlman på engelska, som José inte förstår, att han borde återkomma en annan gång, men då ensam så att samtalet inte blir så folkligt förenklat och konventionellt som det blir i sällskap med människor av Josés sort. Författaren är besviken och äcklad och fattar omedelbart beslutet att aldrig återse mannen, José är dock imponerad och tycker att mannen är klok och har rätt (jfr LR 119-123). Denna Josés skenbart paradoxala inställning

13 Juan Domingo Perón (1895-1974), en argentinsk arméöverste och Argentinas president 1946-1955 och 1973-1974. 
kan förklaras med hans oargentinska dvs uruguayanska ursprung (jfr ovan), samt med att lyxlivet som mannen njuter av är just ett sådant som José med rötter i en fattig miljö drömmer om (jfr LR 123-124).

\section{"Framme vid en insikt"}

Namnet på det avslutande avsnittet i boken, "Obera" (jfr 158-177), hänvisar till en småstad i norra Argentina. Det är kanske symptomatiskt att det kommer i texten strax efter ett av de två detaljrikt beskrivna sexuella umgängena i $L R$ (se ovan; 139-141); det företas av en prostituerad argentinsk tjej och den betalande kunden Kihlman. Symboliken för den (ny)koloniserande västvärlden och det (ny)koloniserade Sydamerika kan i vår tolkning vara relevant, speciellt med tanke på att den nästan avslutar boken.

Att besöka Obera känns för författaren som en förpliktelse, ty det bor många utlänningar i småstaden och dess omnejd, tyskar, ryssar, polacker - samt Kihlmans landsmän, finska emigranter, oftast redan i andra och tredje generation. Där lyckas han och José träffa tre äldre, snarast uråldriga människor som ännu minns sitt ursprungliga hemland som de lämnade under sin barndom eller ungdom för många årtionden sedan, samt dottern och sonen till en av gamlingarna. De stannar i två dygn hos sonen vid namn Reino som är född i Argentina. Reino bor på landet och har en spanskspråkig hustru och åtta barn.

Det går fortfarande att tala finska och svenska med emigranterna, ibland måste enstaka spanska inslag hjälpa till vid kommunikationen. Reinos mor kan fortfarande sjunga finska sånger, hennes son som aldrig varit med om någon demokratiseringsprocess i efterkrigstidens Finland har svårt att säga "du". Emigranterna använder en konservativ och enkel klädsel och är fromma och religiösa. (159, 161-162, 166, 171) Den fattiga trakten med smala och dåliga vägar beskrivs som "de glömdas landskap" (159), en del av "fattigargentina" (162). Enkla, odramatiska ord som de ursprungliga finnarna använder stämmer väl överens med deras ödmjukhet. De ler då och då men skrattar aldrig. De har levt hela sitt liv här, arbetat hårt och varit fattiga $(162,163,165,170,171)$.

Kapitlet "Obera" öppnar således en historia om livets hårda villkor, om folket från Finland som en gång för länge sedan kom hit "[...] som till det förlovade landet, lockade av fagra ord, som ingen täckning hade i verkligheten. Det var den gamla historien om felslagna förhoppningar och drömmar som snabbt föll i grus. Det hade varit att byta ut en fattigdom mot en annan, [...]" (163). Jorden i Oberas trakt var röd och mager. Längre söderut på la Pampa fanns dock svart bördig jord, men redan upptagen av boskap och av en privat äganderätt, inte tillgänglig för fattigt folk och allra minst för ett utländskt sådant. Förväntan gick över i besvikelse och bitterhet, många av emigranterna dog och andra gav sig av (158, 163-164).

Berättaren blir synligt överrumplad, rörd och ödmjuk själv, lägger patetiska ord om blodsband och rötter $(162,163)$, tror sig ha hittat människor i vars sällskap han äntligen kan andas (172-173).

Vi har nått resans mål. Vi skall fortsätta härifrån till Paraguay, men egentligen skulle vi inte behöva göra det, ty längre än så här kommer vi inte att komma och även om det inte gäller 
José utan bara mig, gäller det indirekt också honom, eftersom det är min resa och han är en del därav. Framme. Icke framme i geografin, men framme vid en insikt, som ännu väntar på sin formulering. Hemma. Jag är inte hemma, men känner mig hemma och det har med dessa människor att göra, ty det är något jag sökt, som jag funnit, människor utan slagg och dessa människor är utan slagg. Alla. Även José. Rena? Nej, inte på det religiösa sättet, som har med rädsla och undergivenhet att göra, utan slaggfria, fria från de lager av orenlighet, som makt, inflytande och rikedom ofrånkomligt bär med sig. (170)

Här kan man försöka formulera den insikt som Kihlman kommit till genom att ta avstamp i det perspektiv som är relevant i den här artikeln. Situationen är full av motsägelser och paradoxer. Carlson påpekar att Kihlmans besök för Oberas invånare är en nostalgisk fläkt från drömmarnas hemland som de förlorat för länge sedan (146) - men att Kihlman som utomstående från ett fjärran land ändå inte har någon nyckel till att leva sig in i de finska emigranternas sociala förhållanden (144). På grund av emigranternas fattigdom, ständiga ansträngning och spår av hårt arbete föreslår Carlson att man ska se på Obera som en anti-idyll i stället för en idyll - men trots detta är emigranterna i berättarens ögon befriade från allt det slagg, som kommer med makten och den materiella rikedomen. För deras del blev västerländskheten till någonting obetydligt och oanvändbart. För den koloniala framgångssagan fanns det aldrig någon plats här (145).

Carlsons tankar kan utvecklas. I hans tolkning bär det finska området i Obera således på ett både symptomatiskt och ironiskt namn, Colonia finlandese, den finska kolonin (jfr LR 166). Oberafinnarna kan ses som en motsats till de flesta av de utlänningar som omnämnts tidigare i boken - de utländska affärsmännen, den mäktige mannen med tyskt ursprung (se ovan) och även svenskarna och danskarna som också kom till Obera, men som senare begav sig av och sökte lyckan eller räddningen på annat håll. Bara finnarna stannade kvar (LR 164).

För de finska emigranternas del är nu de koloniserades och kolonisatörernas hierarki omvänd: som fattiga har de bara tillgång till den magra, röda jorden, medan de argentinska storgodsägarna får ta del av den bördiga svarta. Trots att Reino äger en bit åker och lite skog tvingas han av praktiska skäl som livets villkor dikterar vara anställd som dräng hos en inflytelserik man. Fast han bara är ett par år yngre än Kihlman är han redan utsliten: lönen är liten och nöden stor, benet är sjukt och ryggen trött $(165,167,169,170$, 177). De finländare som för många årtionden sedan stannade kvar i det fattiga hemlandet och inte sökte lyckan i det förlovade Sydamerika representerar nu - med avseende på 1980-talets finländska ekonomiska tillväxt - den lyckade framgångssagan. Därför hamnar Kihlman som deras avkomling nu i en överordnad position till emigranterna.

Som en replikväxling mellan berättaren och Reinos syster tyder på, känner han sig dessutom inte inbjuden i Obera vid ett kort tillfälle under besöket. Enligt henne hör han till en grupp hymlande och vänligt nedlåtande finländska författare och journalister som också tidigare varit där och hälsat på. Varför kommer ni, frågar kvinnan, för att nyfiket titta på det exotiska eländet som man tittar på de tama djuren i en djurpark? Hon undrar också på vilket sätt Kihlman tänker förbättra villkoren för emigranternas tillvaro. Författarens replik att han inte vet någonting om deras liv och inte kan skriva något alls om dem, inte kan göra någonting för dem mer än att respektera dem, gör dock henne lugn och ödmjuk igen (jfr LR 172-173). 
Den sydamerikanske infödingen och stadsbon José är i början av utflykten till Obera på dåligt humör och förstår inte meningen med att åka till "denna kvävande stillastående småstad" $(159,160)$. På slutet upptäcker han att han tycker om att vara på landet och vill inte återvända till Buenos Aires utan stanna i Obera, eller åtminstone komma dit någon annan gång $(177,178)$. Carlson föreslår att "resans mål" ur citatet ovan, också kan gälla behandlingen av kulturella skillnader mellan berättaren och José (144). Han påstår även att ett av de outtalade målen för berättarens resa förverkligas i det ögonblick då José tvingas att se [i Obera] att de västerländska emigranternas liv inte alltid behöver bli en framgångssaga (145). Hänvisningar till José i citatet ovan - att han är en del av författarens resa och att han också är en slaggfri människa - kan tänkas stödja den här tolkningen.

Med anledning av oberafinnarnas inte så lyckliga öde söker Carlson tolkningen i namnet på verket: Livsdrömmen rena. De letade efter sin rena dröm på sätt som inte var konstruktiva eller hållbara (146). Som min och även Carlsons egna ovan nämnda tolkning dock tyder på, kan de finska emigranterna förstås som författarens egen rena dröm i positiv betydelse. Tolkningen är relevant speciellt med tanke på verkets undertitel bok om maktlöshet, som också i samband med formuleringen om människor fria från de lager av orenlighet som bl a makt bär med sig (se citatet ovan) kan få sin preciserade förklaring. Med "makt" kan då särskilt menas den koloniala makten, som oberafinnarna inte är en del av. De är däremot själva exploaterade, lider av samma fattigdoms- och jordlöshetsproblem som alla andra vanliga sydamerikanska bönder, och drar ingen nytta av Argentinas underställda position i den orättvisa världshandeln.

\section{Avslutning}

Den saidska analysramen - i detta fall kombinerad med det specifika för just Sydamerika - har visat sig produktiv även för $L R s$ undersökning. Trots att Kihlmans attityd till de behandlade ämnena allmänt sett går i linje med AMS (se inledningen) visar analysen att det knappast är hållbart att påstå att den andra Sydamerika-boken bara utgör en variation på den första eller på författarens alla tidigare verk. $L R$ både utvecklar och kompletterar $A M S$ och det går att betrakta dem som två verk i dialog med varandra, formande en Sydamerika-enhet eller -diptyk, vilket berättigar att de forskas på parallellt med varandra.

I $L R$ har Kihlman inte längre ansett några av sina "postkoloniala" ämnen ur den tidigare boken AMS nödvändiga att diskutera, medan andra (despoti, barbari, "den grå massan”) har fått en särskilt omfattande uppmärksamhet. I $L R$ koncentreras även behandlingen av ämnena till några enstaka avsnitt (som lunch med ambassadören och besök hos den rike mannen), där de får en dialogisk eller retorisk form eller som i det första fallet når en metanivå. Berättarjagets inställning till de kolonialistiska ämnena är i flera fall skarpare (dvs mer negativ) än i AMS. Om jag funnit AMS innehålla en komplex och många gånger ambivalent struktur vad det koloniala tänkandet beträffar (jfr Dlask) är denna ambivalens för $L R$ s del mindre, fast den även här är befintlig t ex med anledning av sättet på vilket berättaren tematiserar den sydamerikanska polisiära makten.

En speciellt symbolisk betydelse har slutkapitlet "Obera". I AMS misslyckas Juans "kolonisering" i syfte att fortsätta karriären som professionell musiker i västvärlden och 
Nordeuropa, ty hans livsfilosofi har inte några förutsättningar för projektet som planerats av den västerländska författaren (jfr Dlask). $L R$ avslutas i och med att José inser att även västerlänningar inte alltid behöver bli framgångsrika i en koloni, utan där också kan hamna i en underställd position. Symptomatiskt är att de i detta fall kommer från författarens hemland. De båda misslyckandena som västvärlden lider av i Sydamerika-böckerna kan ses som Kihlmans parallella yttranden angående den koloniala tematiken med vilka han kan anses försöka "dekolonisera" Sydamerika. Det bör noteras ännu en gång att yttrandena fälldes före det bredare genombrottet av det postkoloniala tänkandet.

Det är anmärkningsvärt att Kihlmans sydamerikanska projekt i stort sett avslutas i o m avsnittet "Obera". Med undantag av ett kort kapitel i hans följande bok, På drift i förlustens landskap (1986) (jfr 40-47), återvänder han aldrig mer till Latinamerika i sin produktion. Meningen "The mission is fu[1]filled." ur hans tidigare bok AMS (251) borde kanske ha satts först till LRs slut. ${ }^{14}$

\section{BIBLIOGRAFI}

Alhoniemi, Pirkko. Isät, pojat, perinnöt. Christer Kihlmanin ja Bertel Kihlmanin kirjallisesta tuotannosta. Helsinki: Suomalaisen Kirjallisuuden Seura, 1989.

Carlson, Mikko. Paikantuneita haluja. Seksuaalisuus ja tila Christer Kihlmanin tuotannossa. Nykykulttuurin tutkimuskeskuksen julkaisuja 114. Jyväskylä: Jyväskylän yliopistopaino, 2014.

Coronil, Fernando. "Latin American postcolonial studies and global decolonization." The Cambridge Companion to Postcolonial Literary Studies. Ed. Neil Lazarus. Cambridge/New York: Cambridge University Press, 2004. 221-240.

Dlask, Jan. "Christer Kihlman's autobiography Alla mina söner (1980; All My Sons) in the perspective of Orientalism (1978) by Edward W. Said". I tryck.

Kihlman, Christer. Alla mina söner. Söderström, 1980.

Kihlman, Christer. Livsdrömmen rena. Bok om maktlöshet. Söderström, 1982.

Kihlman, Christer. På drift i förlustens landskap. Söderström, 1986.

Kuhalampi, Anja. "Muiden kapina - toiseus Christer Kihlmanin tuotannossa." Me ja muut. Etnisyys, identiteetti, toiseus. Ed. Marjo Kylmänen. Tampere: Vastapaino, 1994. 57-67.

Said, Edward W. Orientalism. Modern classics. London: Penguin, 2003.

Tarkka, Pekka. Författare i Finland. Övers. Gunilla Cleve. Helsinki: Tammi, 1990.

Toiviainen, Seppo. Christer Kihlman ja hänen maailmansa. Tutkijaliiton julkaisusarja 32. Jyväskylä: Gummerus, 1984.

Westö, Mårten - Kihlman, Christer. Om hopplöshetens möjligheter. En samtalsbok. Söderström, 2000.

Young, Robert J. C. Postcolonialism : an historical introduction. Malden/Oxford/Carlton: Blackwell Publishing, 2001.

Jan Dlask

Charles University in Prague

jan.dlask@ff.cuni.cz

14 The work on this article was supported by the European Regional Development Fund-Project "Creativity and Adaptability as Conditions of the Success of Europe in an Interrelated World" (No. CZ.02 .1.01/0.0/0.0/16_019/0000734). 